\title{
Observation of Synergistic Effect of End Statin and Cisplatin on Calu-6 Cell
}

\author{
Xin Cheng ${ }^{\mathrm{a}}$, Qiuju Lin ${ }^{\mathrm{b}}$ and Wenhui $\mathrm{Li}^{\mathrm{c}}$ \\ Qingdao center hospital, China. \\ akameilaqq@163.com, blinqiuju0420@126.com, chuizihaoxue@163.com
}

Keywords: End statin, Calu-6, apoptosis.

\begin{abstract}
End statin is an endogenous inhibitor of angiogenesis, specifically acting on endothelial cells, inhibiting its migration, inducing its apoptosis, thus inhibiting the forming of new vessels and tumor growth. But it is not clear about the synergetic mechanism, action characteristic and best regimen. This paper we choosing Calu-6, the human lung adenocarcinoma cell, to observe end statin with/without cisplatin inhibiting growth and inducing apoptosis and the synergetic effect, to provide the experimental evidence for clinical application. The result indicated that End statin can inhibit growth of Calu-6 cell and induce its apoptosis with the mechanism concerned with the down-regulation of Bcl-2. End statin has synergistic effect with Cisplatin, especially in simultaneous administration of two drugs. End statin maybe has an optimistic dosage of action. The mechanisms of End statins' effect are similar.
\end{abstract}

\section{Introduction}

Recently, the incidence and mortality of lung cancer continue to increase and get highest in all of malignancy. About $80 \%$ of them are non- small cell lung cancer and $50 \%$ of patients given the diagnosis of NSCLC belong to advanced disease. Chemotherapy plays a key role in treatment of advanced NSCLC. But, efficacy of chemotherapy is very limited and the phenomenon of drug resistance in NSCLC is very common.1971 the professor Folk man firstly proposed the theory of tumor depending on angiogenesis. He proposed that the angiogenesis was essential not only in tumor growth, but also in tumor invasion and metastasis. Ant angiogenesis become the first light of morning in tumor therapy [1]. End statin is an endogenous inhibitor of angiogenesis, specifically acting on endothelial cells, inhibiting its migration, inducing its apoptosis, thus inhibiting the forming of new vessels and tumor growth. Recently some research indicated that End statin can directly inhibit tumor cell growth, but the mechanism of action and signal conduction pathway is not very clear. End star is the new recombined human end statin. Clinical trial results indicated that it had a good perspective on clinical application and synergetic effect with chemotherapy. But it is not clear about the synergetic mechanism, action characteristic and best regimen [5, 6]. We choosing Calu-6, the human lung adenocarcinoma cell, to observe end statin with/without cisplatin inhibiting growth and inducing apoptosis, to provide the experimental evidence for clinical application.

\section{Experimental}

\subsection{Cell Culture and Treatment.}

RPMI-1640 (containing 10\% fetal bovine serum) medium was added into a cell culture bottle containing Calu- 6 cell lines and incubated at $37 \mathrm{C}$ for $5 \% \mathrm{CO} 2$. Change medium 1 times for 1 2 days and subculture 1 times in 3 4 days. The cells are round and spindle shaped and grow well in two forms.

\subsection{Determination of Growth Inhibition Rate of Calu-6 by MTT Method.}

In the 5000 / Calu- 6 cell inoculated in 96 hole plate, each hole 200 lug, each with 6 parallel holes, and set the blank control. Set the 5 concentrations of End star, end statin and DDP respectively, End star were $0.01,0.1,1,10,100 \mathrm{up} / \mathrm{ml}$ and end statin were $0.01,0.1,1,10,20 \mathrm{up} / \mathrm{ml}$, DDP were $0.1,1$, 
$10,25,50 \mathrm{up} / \mathrm{ml}$; according to the different requirements, continue to culture $24,48,72,96 \mathrm{~h}$, per hole adding MTT solution $(5 \mathrm{mg} / \mathrm{ml})$ to $20 \mathrm{ul}$. After incubation for 4 hours after culture. Be careful to suck up the supernatant in the hole, add 150ul DMSO to each pore for 10 minutes, so that the crystal can be fully melted. The absorbance value of OD570 after different action time is determined by enzyme labelling instrument. According to the absorbance (A) value, the cell inhibition rate and the volume effect curve were calculated. The experiment was repeated 3 times, and a combination of drugs was set up according to the results of the experiment. The inhibition rate was $\%=(1-$ the average light absorption value e of the medicine group / the average light absorption value of the control group) $* 100 \%$.

\subsection{Detection of Apoptosis and Necrosis Rate of Calu-6 Cells by Annexing V-FITC/PI.}

Gather eugenic Calu-6 lung cancer cells, cell culture bottle accounted for bottom area reached more than $80 \%$, abandoned cultivation liquid bottle, PBS cleaning time, careful collection of cells, count of $1 \times 106 / \mathrm{ml}, 5 \mathrm{ml}$ and $5 \mathrm{~min}$, centrifugal 1000rpm, the cells sink at the tube bottom. Straw net absorption of supernatant and cell lysate suspension cells with $1 \mathrm{ml}$ precipitated at room temperature; slight shaking incubation is about 60min; the pyrolysis liquid is transferred to micro centrifuge tube, centrifugal 1000rpm, 15min; and then the tubular clear lysate complete transfer to clean; may precede a white background, direct observation with the naked eye. The deeper the color reaction hole, the stronger the degree of positive and negative reaction is a colorless or very shallow, according to the depth of color was to "+" and "-".

\section{Results and Discussion}

\subsection{Inhibitory Effect of End Star, End Statin and DDP on Calu-6 Cells.}

The results showed that the dose effect curve of DDP inhibiting the growth of Calu- 6 cells showed a significant time and dose dependence. The dose-response curves of End star and end statin inhibits the growth of Calu- 6 cells significantly in a certain range of time dependent but not dose dependent, but both at the concentration of $1 \mathrm{up} / \mathrm{ml}$ effect is the most significant, then increase the dose cell inhibition rate decreased, end statin End star on Calu- 6 cells and 48h, 24h $72 \mathrm{~h}$ and $96 \mathrm{~h}$ between the inhibition rate was no significant difference $(\mathrm{P}>0.05), 24 \mathrm{~h}$ and $72 \mathrm{~h}$ between $24 \mathrm{~h}$ and $96 \mathrm{~h}$, and between $48 \mathrm{~h}$ and $72 \mathrm{~h}, 48 \mathrm{~h}$ and $96 \mathrm{~h}$ were significantly different between $(\mathrm{P}<0.05)$. Selecting the inhibition of Endiostar and end statin $1 \mathrm{up} / \mathrm{ml} 72 \mathrm{~h}$ with the same concentration at the same time points of DDP were compared, results showed that the inhibition of End star and end statin $1 \mathrm{up} / \mathrm{ml} 72 \mathrm{~h}$ is lower than DDP,compared with the same concentration at the same time, and there is significant difference (End star vs. DDP $q=9.68, \mathrm{P}<0.05$ vs. DDP, $\mathrm{q}=7.67, \mathrm{P}<0.05$ ) (Table 1)

Table 1 Inhibition rate of Calu- 6 cells by different time and concentration drugs $(\%, \bar{x} \pm \mathrm{s})$

\begin{tabular}{|c|c|c|c|c|c|c|c|c|c|c|c|c|}
\hline \multirow{2}{*}{$\begin{array}{c}\text { Drug } \\
\text { concentration }\end{array}$} & \multicolumn{4}{|c|}{ End star } & \multicolumn{4}{|c|}{ End statin } & \multicolumn{4}{|c|}{ DDP } \\
\hline & $24 \mathrm{~h}$ & $48 \mathrm{~h}$ & $72 \mathrm{~h}$ & $96 \mathrm{~h}$ & $24 \mathrm{~h}$ & $48 \mathrm{~h}$ & $72 \mathrm{~h}$ & $96 \mathrm{~h}$ & $24 \mathrm{~h}$ & $48 \mathrm{~h}$ & $72 \mathrm{~h}$ & $96 \mathrm{~h}$ \\
\hline 1 & $\begin{array}{c}10.32 \\
\pm \\
1.32\end{array}$ & $\begin{array}{c}10.21 \\
\pm \\
1.41\end{array}$ & $\begin{array}{c}18.32 \\
\pm \\
2.05\end{array}$ & $\begin{array}{c}19.56 \\
\pm \\
2.34\end{array}$ & $\begin{array}{c}12.03 \\
\pm \\
0.92\end{array}$ & $\begin{array}{c}12.26 \\
\pm \\
1.24\end{array}$ & $\begin{array}{c}20.13 \\
\pm \\
1.94\end{array}$ & $\begin{array}{c}18.96 \\
\pm \\
2.10\end{array}$ & $\begin{array}{c}6.56 \pm \\
3.21\end{array}$ & $\begin{array}{c}11.96 \\
\pm \\
3.15\end{array}$ & $\begin{array}{c}32.46 \\
\pm \\
3.08\end{array}$ & $\begin{array}{c}41.26 \\
\pm \\
2.86\end{array}$ \\
\hline 2 & $\begin{array}{c}12.37 \\
\pm \\
3.21\end{array}$ & $\begin{array}{c}11.32 \\
\pm \\
2.63\end{array}$ & $\begin{array}{c}17.96 \\
\pm \\
2.48\end{array}$ & $\begin{array}{c}16.96 \\
\pm \\
2.82\end{array}$ & $\begin{array}{c}11.21 \\
\pm \\
2.31\end{array}$ & $\begin{array}{c}10.39 \\
\pm \\
3.24\end{array}$ & $\begin{array}{c}21.34 \\
\pm \\
1.92\end{array}$ & $\begin{array}{c}20.09 \\
\pm \\
1.36\end{array}$ & $\begin{array}{c}8.92 \pm \\
2.81\end{array}$ & $\begin{array}{c}21.32 \\
\pm \\
2.34\end{array}$ & $\begin{array}{c}40.56 \\
\pm \\
1.23\end{array}$ & $\begin{array}{c}50.12 \\
\pm \\
3.41\end{array}$ \\
\hline 3 & $\begin{array}{c}15.03 \\
\pm \\
2.44\end{array}$ & $\begin{array}{c}13.25 \\
\pm \\
3.36\end{array}$ & $\begin{array}{c}25.92 \\
\pm \\
1.24\end{array}$ & $\begin{array}{c}24.32 \\
\pm \\
1.32\end{array}$ & $\begin{array}{c}15.06 \\
\pm \\
1.52\end{array}$ & $\begin{array}{c}14.32 \\
\pm \\
2.51\end{array}$ & $\begin{array}{c}28.08 \\
\pm \\
1.58\end{array}$ & $\begin{array}{c}27.68 \\
\pm \\
1.92\end{array}$ & $\begin{array}{c}12.70 \\
\pm \\
3.71\end{array}$ & $\begin{array}{c}30.56 \\
\pm \\
4.52\end{array}$ & $\begin{array}{c}45.65 \\
\pm \\
2.48\end{array}$ & $\begin{array}{c}62.32 \\
\pm \\
0.95\end{array}$ \\
\hline 4 & $\begin{array}{c}13.2 \pm \\
2.15\end{array}$ & $\begin{array}{c}9.98 \pm \\
1.74\end{array}$ & $\begin{array}{c}20.13 \\
\pm \\
3.72\end{array}$ & $\begin{array}{c}19.12 \\
\pm \\
3.65\end{array}$ & $\begin{array}{c}14.20 \\
\pm \\
2.61\end{array}$ & $\begin{array}{c}13.28 \\
\pm \\
4.32\end{array}$ & $\begin{array}{c}24.04 \\
\pm \\
1.82\end{array}$ & $\begin{array}{c}21.98 \\
\pm \\
3.62\end{array}$ & $\begin{array}{c}15.82 \\
\pm \\
1.32\end{array}$ & $\begin{array}{c}36.56 \\
\pm \\
2.61\end{array}$ & $\begin{array}{c}50.12 \\
\pm \\
1.93\end{array}$ & $\begin{array}{c}72.74 \\
\pm \\
3.45\end{array}$ \\
\hline 5 & $\begin{array}{c}15.49 \\
\pm \\
1.54\end{array}$ & $\begin{array}{c}12.36 \\
\pm \\
2.33\end{array}$ & $\begin{array}{c}24.32 \\
\pm \\
1.92\end{array}$ & $\begin{array}{c}22.33 \\
\pm \\
2.03\end{array}$ & $\begin{array}{c}12.32 \\
\pm \\
4.72\end{array}$ & $\begin{array}{c}10.21 \\
\pm \\
3.74\end{array}$ & $\begin{array}{c}22.06 \\
\pm \\
2.91\end{array}$ & $\begin{array}{c}20.56 \\
\pm \\
4.20\end{array}$ & $\begin{array}{c}29.10 \\
\pm \\
2.71\end{array}$ & $\begin{array}{c}42.01 \\
\pm \\
4.32\end{array}$ & $\begin{array}{c}54.32 \\
\pm \\
1.84\end{array}$ & $\begin{array}{c}75.36 \\
\pm \\
1.92\end{array}$ \\
\hline
\end{tabular}




\subsection{Inhibitory Effect of End Star, End Statin and DDP on Calu-6 Cells}

The apoptosis was detected by $72 \mathrm{~h}$ post flow cytometer (Figure 4). Annexing V-FITC/PI was used to detect early apoptosis. Late apoptotic cells failed to be detected due to the time of experimental selection, so the percentage of necrotic cells was counted together (Table 3). End star, end statin immunotherapy compared with the control group apoptosis rate increased $(\mathrm{P}<0.05)$, necrotic cells increased significantly, but less than the single drug DDP $(\mathrm{P}<0.05)$. The cell apoptosis / necrosis rate was no significant difference in End star, end statin and DDP sequential therapy group and single drug group DDP, but the simultaneous treatment group $(7,10)$ than the single drug group DDP apoptosis / necrosis rate increased, and there was statistical significance $(\mathrm{P}<0.05)$. Between End star and end statin corresponding groups $(2 \mathrm{vs} 3,5 \mathrm{vs} 8,6 \mathrm{vs} 9,7 \mathrm{vs} 10)$ had no significant difference $(\mathrm{P}>0.05)$.

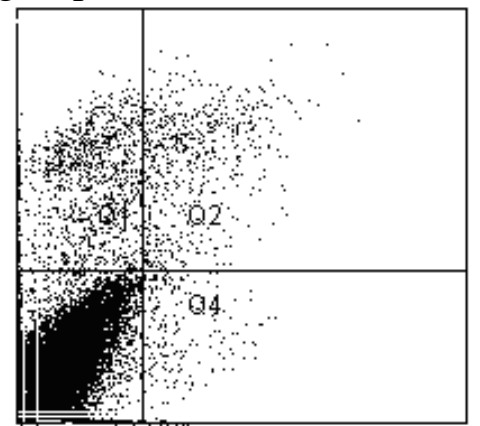

Control group (1)

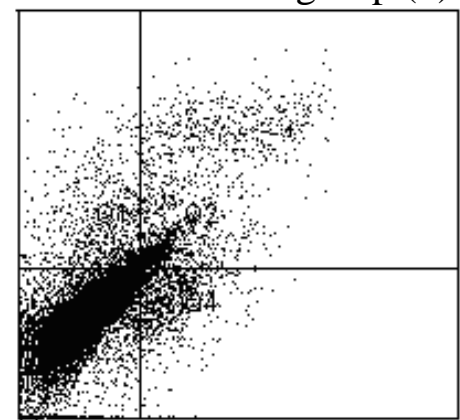

End star (2)

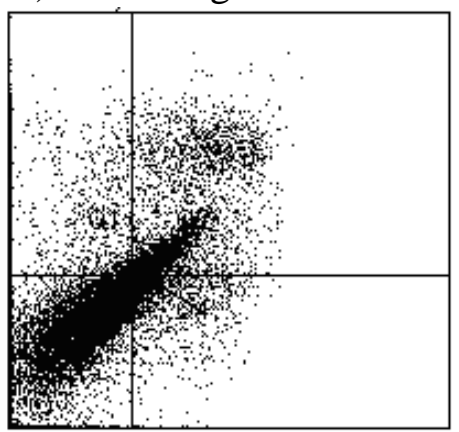

DDP (4)

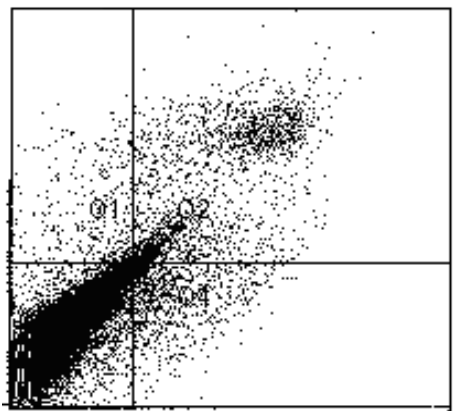

End statin (3)
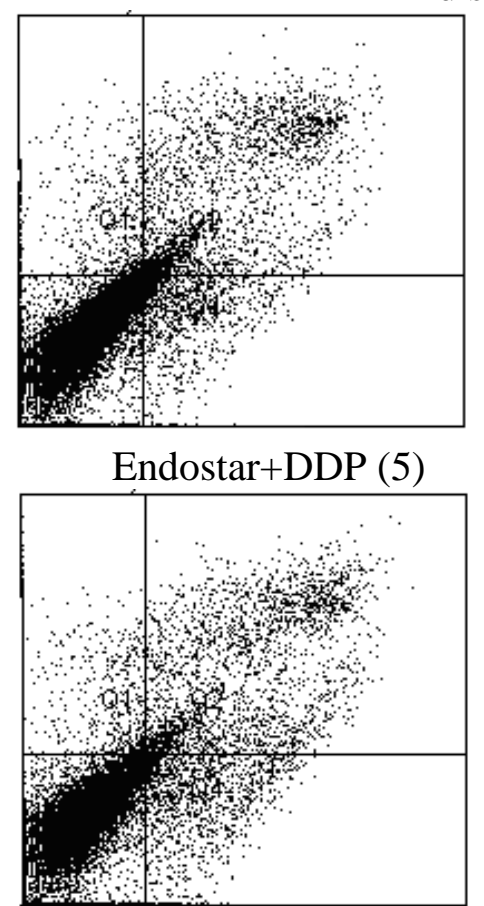

Endostatin+DDP (8)

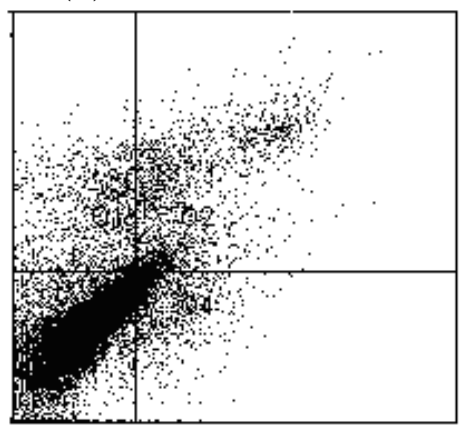

DDP+Endostar(6)

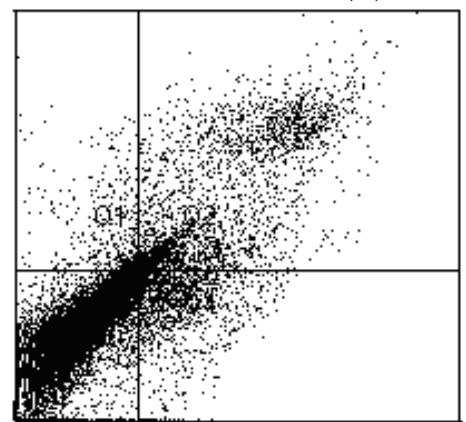

DDP+Endostatin (9)

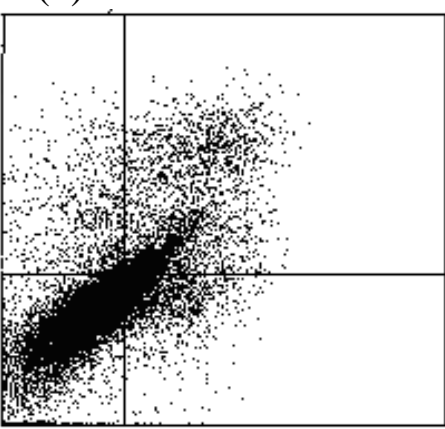

End star/ DDP (7)

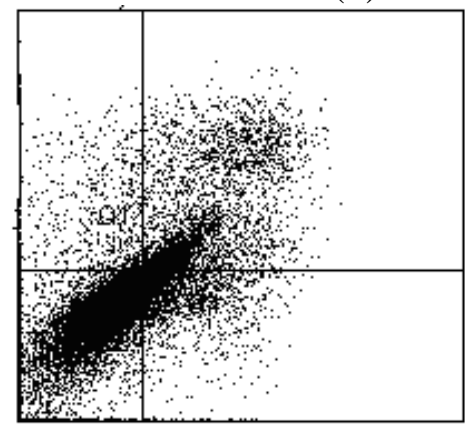

End statin / DDP (10)

Figure 1. Detection of apoptosis / necrosis rate of Calu- 6 cells by Annexin V-FITC/PI 


\subsection{Inhibitory Effect of End Star, End Statin and DDP on Calu-6 Cells}

Compared with the control group, the single drug End star and end statin can reduce the exprsssion of Bcl-2 ( $\mathrm{P}<0.05)$, but less than the single drug DDP $(\mathrm{P}<0.05)$, sequential administration group $(5,6$, $8,9)$ was no significant difference compared with the DDP group, but the simultaneous treatment group $(7,10)$ than in group DDP $(\mathrm{P}<0.05)$ significantly reduced the expression of $\mathrm{Bcl}-2$. Each group of Endostar and endostatin corresponding between $(2 \mathrm{vs} 3,5 \mathrm{vs} 8,6 \mathrm{vs} 9,7 \mathrm{vs} 10)$ showed no significant difference $(\mathrm{P}>0.05)$. There was no obvious effect on the expression of Box in end statin, End star, DDP immunotherapy and combined therapy ( $\mathrm{P}>0.05)$. DDP, Endostar and endostatin monotherapy and combination regimen were not detected the expression of sFas. (Table 2).

Table 2. LISA determination of the expression of apoptosis related protein in Calu- 6 cells

\begin{tabular}{ccccc}
\hline \multicolumn{6}{c}{ Expression of apoptosis related protein in Calu-6 cells $(\bar{x} \pm$ sang/ml) } \\
Group & Bcl-2 & Bax & sFas & seas \\
(1) & $4.89 \pm 0.95$ & $4.12 \pm 0.08$ & - & - \\
$(2)$ & $3.71 \pm 0.12^{*}$ & $4.04 \pm 0.20$ & - & - \\
$(3)$ & $3.59 \pm 0.13^{*}$ & $3.75 \pm 0.24$ & - & - \\
$(4)$ & $2.69 \pm 0.21^{*}$ & $3.57 \pm 0.35$ & - & - \\
$(5)$ & $2.61 \pm 0.44^{*}$ & $3.88 \pm 0.11$ & - & - \\
$(6)$ & $2.80 \pm 0.47^{*}$ & $3.94 \pm 0.20$ & - & - \\
$(7)$ & $2.14 \pm 0.17^{* *}$ & $3.87 \pm 0.05$ & - & - \\
$(8)$ & $2.59 \pm 0.60^{*}$ & $3.87 \pm 0.14$ & - & - \\
$(9)$ & $2.57 \pm 0.62^{*}$ & $3.84 \pm 0.12$ & - & - \\
$(10)$ & $2.06 \pm 0.09^{* *}$ & $3.46 \pm 0.15$ & - & - \\
\hline
\end{tabular}

\section{Conclusion}

End statin can inhibit the growth of Calu- 6 cell and induce its apoptosis with the mechanism concerned with the down-regulation the expression of Bcl-2. End statin has synergistic effect with Cisplatin, especially in simultaneous administration of two drugs. End statin maybe has an optimistic dosage of action. The mechanisms of End statins' effect are similar.

\section{References}

[1]. Folk man Joule of angiogenesis in tumor growth and metastasis. Semen Uncool, vol.29 (2002) No6, p.15-18.

[2]. O`Reilly MS, Boehm T, Shine Y, et al. Endostatin:an endogenous inhibitor of angiogenesis and tumor growth[J]. Cell, vol.88 (1997) No.2, p.277-285.

[3]. Sasaki T,Fukai Nain Kept a1. Structure, function, and tissue forms of the C-terminal globuarolomain of collagen XVIII containing the amigo-genesis inhibitor end statin[J].EMBO J, vol. 17(1998) No.15, p.4249-4256.

[4]. Muragaki Timmons Griffith Commit a1. Mouse toll 8a 1 is ex-pressed in a tissue-specific manner as three alternative variants and is localized in basement membrane zones[J]. Proem Nat'l Accad Sic USA, vol.92 (1959) No.19, p.8763-8767.

[5]. Stander Schrader Maine Seat a1. Isolation and characterize-tin of the circulating form of human end statin [J]. Fibs Let, vol.420(1997) No.2-3, p.129-133.

[6]. Yamaguchi N,Anand-Apte Bale Met al.Endostatin inhibits VEGF-induced endothelial cell migration and tumor growth independently of zinc binding [J].EMBO J, vol.18(1999) No.16, p.4414-4423. 